\title{
Features of the bony orbit of the Baikal seal: comparative studies
}

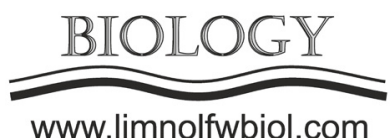

\author{
Marchukov K.K., Karpova E.A.* \\ Irkutsk State Agricultural University named after A.A. Ezhevsky, Timiryazeva Str. 59 Irkutsk, 664007, Russia
}

\begin{abstract}
The research purpose is to study features of the bony orbit of the Baikal seal in comparison with another representative of aquatic mammals - the fur seal. In the Baikal seal, the bony orbit is open; it lacks the zygomatic process of the frontal bone; the frontal bone and the zygomatic arch are connected by the orbital ligament, which forms a posterolateral edge of the orbit. The Baikal seal has a spherical bony orbit located on the front skull surface. The fur seal has an elliptical bony orbit located on the lateral skull surface. It also lacks the zygomatic process of the frontal bone. The orbit is of an open type. Therefore, in the Baikal seal, the field of vision is narrower than that in the fur seal. It is due to the fact that in natural conditions the Baikal seal has no natural enemies, while the fur seal is prey for larger predators.
\end{abstract}

Keywords: Baikal seal, bony orbit, skull

\section{Introduction}

During the evolutionary process, the bone orbit of the Baikal seal has undergone a number of changes that reflect both physiological characteristics and good vision both on land and in water.

\section{Material and methods}

The research object was 14 individuals of the Baikal seal. Skulls of the Baikal and fur seals were used as a research material. The following research methods were employed: regional autopsy, dissection, description, photographing, craniometry and morphometry using a ruler and a caliper.

\section{Results}

In the Baikal seal, an open-type eye socket - a typical sign of predators - is located on the front skull surface. The bony orbit is formed by the following bones: the orbital-temporal part of the frontal bone (os frontale), the lacrimal bone (os lacrimale), the orbital wings of the sphenoid bone (ale orbitales); the palatine bone (os palatinum) forms the oblique orbit bottom, the zygomatic bone (os zygomatic), the zygomatic arch of the temporal bone (os temporale). The frontal bone is connected with the zygomatic arch in the orbital ligament, which forms a posterolateral edge of the orbit (Lomako, 2017). The area of adhesion of the frontal and nasal bones is extremely narrow. There are no zygomatic processes of the frontal bone. They do not form the upper part of the orbit.

At the base of the orbital wings of the sphenoid bone, there are two holes: dorsal (a round visual opening) and ventral (an orbital fissure). On the dorsal surface, at the border of the frontal and temporal bones, there is a small, round infraorbital foramen.

The animal develops actively during the first six months. During the next year, the animal continues to grow at a slower pace. Then, the linear growth slows down. By the age of 17-19 years, the bone orbit is of a perfect spherical shape.

A comparative analysis identified differences between the Baikal seal and the fur seal. The fur seal has zygomatic processes of the frontal bone. The shape of its bone orbit is elliptical. In the Baikal seal, eyes are located on the front skull surface, and in the fur seal, they are located on the lateral skull surface (Marchukov and Karpova, 2019). In the Baikal seal, the skull is smaller, but wider due to the zygomatic bone and the zygomatic process of the temporal bone. Moreover, sizes of the bone orbits are almost identical. In the Baikal seal, the eye socket occupies a large part of the skull; in the fur seal, the orbit occupies less than half the skull, since it is larger.

\section{Conclusion}

The frontal bone of the Baikal seal lacks the zygomatic process. The bony orbit is of a perfect spherical shape while the bony orbit of the fur seal 
is elliptical. The eyes of the Baikal seal are located on the front skull surface; in the fur seal, they are located on the lateral skull surface. This is due to the fact that in natural conditions, the Baikal seal has no natural enemies, while the fur seal is prey for larger predators. For the orbit, three development periods were identified: up to six months - the most intense growth; up to 1.5 years - drop in growth; after 1.5 years - significant drop in growth.

\section{References}

Lomako K. 2017. Anatomical and topographic features of the orbit of the Baikal seal. In: Regional'naya NauchnoPrakticheskaya Konferenciya "Nauchnye Issledovaniya Studentov v Reshenii Actual'nyh Problem APK" [Regional Scientific-Practical Conference "Scientific Research of Students Aimed at Solving Urgent Problems of the Agricultural Sector], pp. 447-452. (in Russian)

Marchukov K., Karpova E. 2019. Anatomical features of the bone orbit of the Baikal seal (Pusa sibirica). Regional'naya Nauchno-Prakticheskaya Konferenciya "Nauchnye Issledovaniya Studentov v Reshenii Actual'nyh Problem APK" [Regional Scientific-Practical Conference "Scientific Research of Students Aimed at Solving Urgent Problems of the Agricultural Sector], pp. 100-107. (in Russian) 